\title{
Effect of Additives on the Reversibility of Lithium Alanate $\left(\mathrm{LiAlH}_{4}\right)$
}

\author{
Zheng Xueping1, $\quad$ Li Ping $^{2}, \quad$ Qu Xuanhui ${ }^{2}$ \\ ${ }^{1}$ Chang'an University, Xi'an 710061, China, ${ }^{2}$ University of Science \& Technology Beijing, Beijing 100083, China
}

\begin{abstract}
The effect of various catalysts, such as $\mathrm{Ti}, \mathrm{Ni}, \mathrm{Fe}, \mathrm{Ce}\left(\mathrm{SO}_{4}\right)_{2}$ and $\mathrm{LaCl}_{3}$, on the reversibility of $\mathrm{LiAlH}_{4}$ was studied by Pressure-Content-Temperature (PCT) experiments. The result indicates that doping induces a marked decrease in the rate of hydrogen release. In addition, doping additives obviously decreases the initial temperature of $\mathrm{LiAlH}_{4}$ of hydrogen release except for doping with $\mathrm{LaCl}_{3}$. However, at the same time, the amount of hydrogen release also decreases. In the study on the hydrogen absorption of $\mathrm{LiAlH}_{4}$ doped with $1 \mathrm{~mol} \% \mathrm{Ni}, 1 \mathrm{~mol} \% \mathrm{Ti}, 1 \mathrm{~mol} \% \mathrm{Ce}\left(\mathrm{SO}_{4}\right)_{2}$ and $1 \mathrm{~mol} \% \mathrm{LaCl}_{3}$ at $180{ }^{\circ} \mathrm{C}$ under about $8 \mathrm{MPa}$, it has been found that the sample doped with $1 \mathrm{~mol} \% \mathrm{Ni}$ presents the largest hydrogen absorption amount with about $0.97 \mathrm{wt} \%$.
\end{abstract}

Key words: catalysts; reversibilities; hydrogen release; $\mathrm{LiAlH}_{4}$

The energy infrastructure is facing more serious challenges than ever before due to limited supplies of oil, environmental concerns about $\mathrm{CO}_{2}$ exhaust and exhausts from fossil fuels, and an ever-expanding energy demand in the growing economies in Asia ${ }^{[1,2]}$. It is extensively believed that hydrogen is a potential major alternative energy carrier. However, there is still a problem of storage and transportation for hydrogen. So far, there are three kinds of materials under consideration for use in hydrogen storage processes: nanostructural materials, metals and metal alloy, and complex hydrides (light mass metal alloys). Metal hydrides are considered as one of the most attractive methods. Several interstitial metal hydriges like $\mathrm{LaNi}_{5}, \mathrm{~Pa}$ and TiFe operate at around room temperature. However, their reversible gravimetric hydrogen capacity is limited to $2.5 \mathrm{wt} \%$. This is significantly below the goal of $\geq 5 \mathrm{wt} \%$ hydrogen set recently by the International Energy Agency. Complex hydrides had not been studied for hydrogen storage materials until Bogdanović and Schwichardi ${ }^{[3]}$ reported the reversible hydrogen storage of $\mathrm{NaAlH}_{4}$ with Ti-containing dopants. Complexhydrides such as $\mathrm{NaAlH}_{4}$, $\mathrm{LiAlH}_{4}$ and $\mathrm{LiNH}_{2}$ are superior to conventional hydrogen alloys in both mass and volume densities of hydrogen. For example, the hydrogen contents of $\mathrm{NaAlH}_{4}$ and $\mathrm{LiAlH}_{4}$ can reach $7.4 \%$ to $10.5 \%$ of hydrogen by mass. Theoretically, $\mathrm{NaAlH}_{4}$ can store 5.6wt $\% \mathrm{H}_{2}$ reversibly. However, the theoretical capacity of $\mathrm{LiAlH}_{4}$ is available even with $7.9 \mathrm{wt} \%$ hydrogen below $200{ }^{\circ} \mathrm{C}$. Hydrogen release occurs in three stages ${ }^{[4]}$ :

$$
\begin{aligned}
& 3 \mathrm{LiAlH}_{4} \rightarrow \mathrm{Li}_{3} \mathrm{AlH}_{6}+2 \mathrm{Al}+3 \mathrm{H}_{2} \quad\left(5.3 \mathrm{wt} \% \mathrm{H}_{2}\right) \\
& \mathrm{Li}_{3} \mathrm{AlH}_{6} \rightarrow 3 \mathrm{LiH}+\mathrm{Al}+3 / 2 \mathrm{H}_{2} \quad\left(2.6 \mathrm{wt} \% \mathrm{H}_{2}\right) \\
& 3 \mathrm{LiH}+3 \mathrm{Al} \rightarrow 3 \mathrm{LiAl}+3 / 2 \mathrm{H}_{2} \\
& \text { (2.6 wt } \% \mathrm{H}_{2} \text { ) }
\end{aligned}
$$

The decomposition temperatures are reported to be between 150-175 ${ }^{\circ} \mathrm{C}$ (Ep.(1)) and $180-220{ }^{\circ} \mathrm{C}$ (Ep.(2)) ${ }^{[2,5]}$. The last composition step occurs at $400^{\circ} \mathrm{C}$ which is considered not to be supplied. In recent studies, the focus has been on $\mathrm{LiAlH}_{4}$ prepared by ball-milling process and adding catalysts. The research has shown that adding of catalysts can effect distinctly the decomposition of $\mathrm{LiAlH}_{4}$. The principal catalysts studied wereelemental titanium( $\mathrm{TiCl}_{4}, \mathrm{TiCl}_{3}, \mathrm{AlCl}_{3}, \mathrm{FeCl}_{3}$ ), elemental iron, elemental nickel, vanadium and carbon black ${ }^{[6-8]}$. Mirna $\operatorname{Resan}^{[6]}$ reported that the addition of $\mathrm{TiCl}_{3}$ and $\mathrm{TiCl}_{4}$ to $\mathrm{LiAlH}_{4}$ would eliminate the first step of hydrogen evolution and significantly lower the decomposition temperature of the second step. Doping with elemental iron caused only a slight decrease in the amount of hydrogen released and did not eliminate the first step of hydrogen evolution. The study by Blanchard ${ }^{[7]}$ showed that ball-milling of $\mathrm{LiAlD}_{4}$ and $\mathrm{VCl}_{3}$ or $\mathrm{TiCl}_{3} \cdot 1 / 3 \mathrm{AlCl}_{3}$ would reduce the thermal decomposition temperatures for Eq.(1) by $50-60{ }^{\circ} \mathrm{C}$. 
In the present paper, our research focuses mainly on $\mathrm{LiAlH}_{4}$ with $1 \mathrm{~mol} \% \mathrm{Ni}, 1 \mathrm{~mol} \% \mathrm{Ti}, 1 \mathrm{~mol} \% \mathrm{Fe}, 1 \mathrm{~mol} \% \mathrm{Ce}\left(\mathrm{SO}_{4}\right)_{2}$ and $1 \mathrm{~mol} \% \mathrm{LaCl}_{3}$. Our purpose is to show their effects on the release hydrogen capacity in the first and second step decomposition reaction.

\section{Experimental}

$\mathrm{LiAlH}_{4}(\geq 96 \mathrm{wt}$ \% pure) was purchased from Tianjin Beidouxing Fine Chemical Co.,Ltd. The nickel powder, Ti, Fe, $\mathrm{Ce}\left(\mathrm{SO}_{4}\right)_{2} \cdot 4 \mathrm{H}_{2} \mathrm{O}$ and $\mathrm{LaCl}_{3} \cdot 7 \mathrm{H}_{2} \mathrm{O}$ were obtained from Central Iron and Steel Research Institute. $\mathrm{LiAlH}_{4}, \mathrm{Ti}, \mathrm{Fe}$ and $\mathrm{Ni}$ were used as received with no additional purification. Due to a mass of crystal water in $\mathrm{Ce}\left(\mathrm{SO}_{4}\right)_{2} \cdot 4 \mathrm{H}_{2} \mathrm{O}$ and $\mathrm{LaCl}_{3} \cdot 7 \mathrm{H}_{2} \mathrm{O}$, dehydration was carried out before $\mathrm{LiAlH}_{4}$ was mixed with $\mathrm{Ce}\left(\mathrm{SO}_{4}\right)_{2}$ and $\mathrm{LaCl}_{3}$ in order to prevent the effect of the crystal water on $\mathrm{LiAlH}_{4} \cdot \mathrm{Ce}\left(\mathrm{SO}_{4}\right)_{2} \cdot 4 \mathrm{H}_{2} \mathrm{O}$ and $\mathrm{LaCl}_{3} \cdot 7 \mathrm{H}_{2} \mathrm{O}$ were heated to 160 and $150{ }^{\circ} \mathrm{C}$ and then kept at these temperatures for 4 and $3 \mathrm{~h}$, respectively. All operations on the samples were done under dry argon atmosphere in a glove box to prevent the reaction moisture with oxygen in the air. $\mathrm{LiAlH}_{4}$, usually with $2 \mathrm{~g}$, was mixed with $1 \mathrm{~mol} \% \mathrm{Ni}, \mathrm{Ti}, \mathrm{Fe}, \mathrm{Ce}\left(\mathrm{SO}_{4}\right)_{2}$ and $\mathrm{LaCl}_{3}$ by ball-milling for $20 \mathrm{~min}$ at a gyration rate of $200 \mathrm{r} / \mathrm{min}$ using a Spex mill. Three hardened steel vials sealed under argon with fourteen steel balls ( $1 \mathrm{~g}$ each) were used. Air-cooling of the vials was employed to prevent heating during the ball-milling process. The ball-milled samples were then transferred to $3 \mathrm{~mL}$ glass bottles in a glove box under dry argon atmosphere.

Hydrogen desorption experiments were carried out in pressure-composition- temperature (PCT) apparatus, which can be operated up to $10 \mathrm{MPa}$ and at $400{ }^{\circ} \mathrm{C}$. The pressure of hydrogen released in relation to volume was displayed by a pressure transducer. The experimental studies were done by a reactor. It consisted of two parts: heater and sample vessel. The heater was used to connect with the pressure transducer and thermocouple. It had a $2.2 \mathrm{~cm}$ outside diameter (OD), $0.5 \mathrm{~cm}$ wall and $20 \mathrm{~cm}$ internal length, and was loaded with the sample vessel ( $1 \mathrm{~cm} \mathrm{OD,} 0.1 \mathrm{~cm}$ wall and $5 \mathrm{~cm}$ internal length). The sample vessel was loaded with about $0.2 \mathrm{~g}$ of $\mathrm{LiAlH}_{4}$. The reactor was heated with an air furnace. During heating, the hydrogen released overflowed from the sample vessel firstly into the heater and then into the transit pressure transducer. The value of hydrogen pressure can be clearly read. The samples doped with $\mathrm{Ni}, \mathrm{Ti}, \mathrm{Ni}, \mathrm{Ce}\left(\mathrm{SO}_{4}\right)_{2}$ and $\mathrm{LaCl}_{3}$ were heated at a heating rate of $2{ }^{\circ} \mathrm{C} / \mathrm{min}$ to $250{ }^{\circ} \mathrm{C} / \mathrm{min}$ in a vacuum atmosphere. During the heating process, all pressure and temperature data were acquired and then the first step and the second step curves were drawn by special software.

Rehydrogenation studies were carried out with $\mathrm{LiAlH}_{4}$ doped with $1 \mathrm{~mol} \% \mathrm{LaCl}_{3}, \mathrm{Ce}\left(\mathrm{SO}_{4}\right)_{2}$, Ti and $\mathrm{Ni}$, respectively. After the first complete dehydrogenation (first two reactions), the samples were kept at $180{ }^{\circ} \mathrm{C}$ under $\sim 8 \mathrm{MPa}$ hydrogen pressure for $2 \mathrm{~h}$. The uptake of hydrogen for the samples was evident by the pressure decreasing with time in this closed system. The change of hydrogen pressure was recorded by the pressure transducer.

\section{Results and Discussion}

Fig.1 shows the thermal decomposition process of the samples doped with metal elements, such as, $1 \mathrm{~mol} \% \mathrm{Ni}, 1$ mol\% Ti and $1 \mathrm{~mol} \% \mathrm{Fe}$. The results show that doping induces a marked decrease in the dehydrogenation temperature in the first step. It can be seen that doping with Fe causes the lowest temperature and amount of hydrogen release in the first and second steps. Doping with Ti also causes a significant decrease in the temperature and amount of hydrogen release in the first step while the amount of hydrogen release in the second step only has a slight decrease. Comparatively, doping with $\mathrm{Ni}$ presents the largest amount of hydrogen release and the highest dehydrogenation temperature in the first and second step. The slops indicates doping induces a marked decrease in the rate of hydrogen release. In particular, doping with Fe presents the lowest dehydrogenation rate in the first and second steps. On the contrary, doping with $\mathrm{Ni}$ presents the largest rate of hydrogen release in the two-step dehydrogenation.

Fig.2 gives the thermal decomposition of the samples doped with $\mathrm{Ce}\left(\mathrm{SO}_{4}\right)_{2}$ and $\mathrm{LaCl}_{3}$. Doping with $\mathrm{Ce}\left(\mathrm{SO}_{4}\right)_{2}$ cases a significant decrease in the temperature of $h$ ydrogen release in the first step while the dehydrogenation amount in the first step has no significant change compared to $\mathrm{LiAlH}_{4}$ undoped. In the second step of dehydrogenation, doping with $\mathrm{Ce}\left(\mathrm{SO}_{4}\right)_{2}$ causes a marked decrease in the second step. However, it is different from the results that doping with $\mathrm{Ni}, \mathrm{Ti}, \mathrm{Fe}$ and $\mathrm{Ce}\left(\mathrm{SO}_{4}\right)_{2}$ induces a significant decrease in the temperature, while doping with $\mathrm{LaCl}_{3}$ causes a marked decrease in the amount of hydrogen release. The slopes of curves indicates that doping with $\mathrm{Ce}\left(\mathrm{SO}_{4}\right)_{2}$ and $\mathrm{LaCl}_{3}$ induces a decrease in the first dehydrogenation rate.

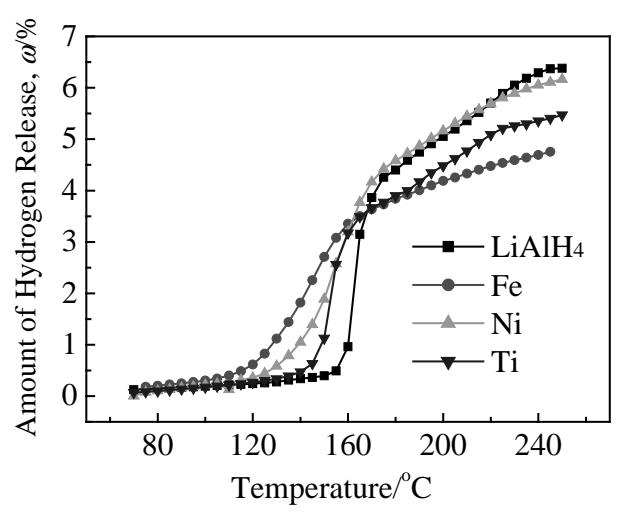

Fig.1 Thermal dehydrogenation of $\mathrm{LiAlH}_{4}$ and $\mathrm{LiAlH}_{4}$ doped with $1 \mathrm{~mol} \% \mathrm{Ni}$, Ti and $\mathrm{Fe}$ 


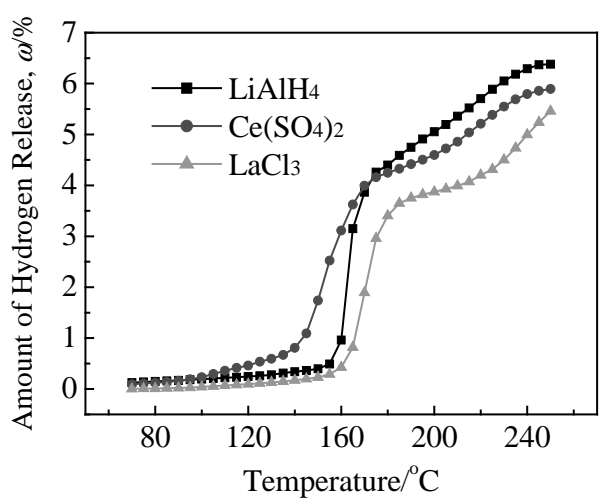

Fig.2 Thermal dehydrogenation of $\mathrm{LiAlH}_{4}$ and $\mathrm{LiAlH}_{4}$ doped with $1 \mathrm{~mol} \% \mathrm{Ce}\left(\mathrm{SO}_{4}\right)_{2}$ and $\mathrm{LaCl}_{3}$

Table 1 gives the amount and temperature of hydrogen release of $\mathrm{LiAlH}_{4}$ undoped and doped with $1 \mathrm{~mol} \% \mathrm{Ni}, 1 \mathrm{~mol} \% \mathrm{Ti}$, $1 \mathrm{~mol} \% \mathrm{Fe}, 1 \mathrm{~mol} \% \mathrm{Ce}\left(\mathrm{SO}_{4}\right)_{2}$ and $1 \mathrm{~mol} \% \mathrm{LaCl}_{3}$ in the first and second steps, respectively. The dehydrogenation amount of $\mathrm{LiAlH}_{4}$ undoped is $4.0 \mathrm{wt} \%$ in the first step and $2.0 \mathrm{wt} \%$ in the second step, respectively. The initial temperature is $147{ }^{\circ} \mathrm{C}$. Doping obviously decreases the initial temperature of hydrogen release except for doping with $\mathrm{LaCl}_{3}$. However, at the same time, the amount of hydrogen release also decreases. Doping with $\mathrm{Fe}$ induces the lowest temperature and amount of hydrogen release. Doping with Ni decreases the dehydrogenation temperature by $27{ }^{\circ} \mathrm{C}$ while the amount of hydrogen release has only a slight decrease.

Fig. 3 gives the absorption curves of $\mathrm{LiAlH}_{4}$ doped with 1 $\mathrm{mol} \% \mathrm{Ni}, 1 \mathrm{~mol} \% \mathrm{Ti}, 1 \mathrm{~mol} \% \mathrm{Ce}\left(\mathrm{SO}_{4}\right)_{2}$ and $1 \mathrm{~mol} \% \mathrm{LaCl}_{3}$ at $180{ }^{\circ} \mathrm{C}$ under about $8 \mathrm{MPa}$. It is clear to see that the sample doped with $1 \mathrm{~mol} \% \mathrm{Ni}$ presents the lowest hydrogen pressure which indicates doping with $\mathrm{Ni}$ has the largest hydrogen absorption amount with about $0.97 \mathrm{wt} \%$ (Table 2). However, doping with $1 \mathrm{~mol} \% \mathrm{Ce}\left(\mathrm{SO}_{4}\right)_{2}$ induces the lowest hydrogen adsorption amount with about $0.14 \mathrm{wt} \%$.

Table 1 The dehydrogenation amount and temperature of $\mathrm{LiAlH}_{4}$ and $\mathrm{LiAlH}_{4}$ doped with $1 \mathrm{~mol} \% \mathrm{Ni}, \mathrm{Ti}, \mathrm{Fe}, \mathrm{Ce}\left(\mathrm{SO}_{4}\right)_{2}$ and $\mathrm{LaCl}_{3}$ in the first (R1) and second steps $(\mathrm{R} 2)(\omega / \%)$

\begin{tabular}{cccccc}
\hline Sample & $\mathrm{R} 1$ & $\mathrm{R} 2$ & $\begin{array}{c}\text { Initial } \\
\text { temperature } /{ }^{\circ} \mathrm{C}\end{array}$ & $\begin{array}{c}\text { End } \\
\text { temperature } /{ }^{\circ} \mathrm{C}\end{array}$ & $\begin{array}{c}\text { Total } \\
\text { amount }\end{array}$ \\
\hline $\mathrm{LiAlH}_{4}$ & 4.0 & 2.0 & 147 & 245 & 6.0 \\
$1 \mathrm{~mol} \%$ & 4.0 & 1.6 & 120 & 245 & 5.6 \\
$\mathrm{Ce}\left(\mathrm{SO}_{4}\right)_{2}$ & & & & & \\
$1 \mathrm{~mol} \%$ & 3.6 & 1.8 & 150 & 250 & 5.4 \\
$\mathrm{LaCl}_{3}$ & & & & & \\
$1 \mathrm{~mol} \% \mathrm{Ni}$ & 4.1 & 1.6 & 120 & 250 & 5.7 \\
$1 \mathrm{~mol} \% \mathrm{Ti}$ & 3.5 & 1.9 & 130 & 240 & 5.4 \\
$1 \mathrm{~mol} \% \mathrm{Fe}$ & 3.3 & 1.2 & 110 & 246 & 4.5 \\
\hline
\end{tabular}

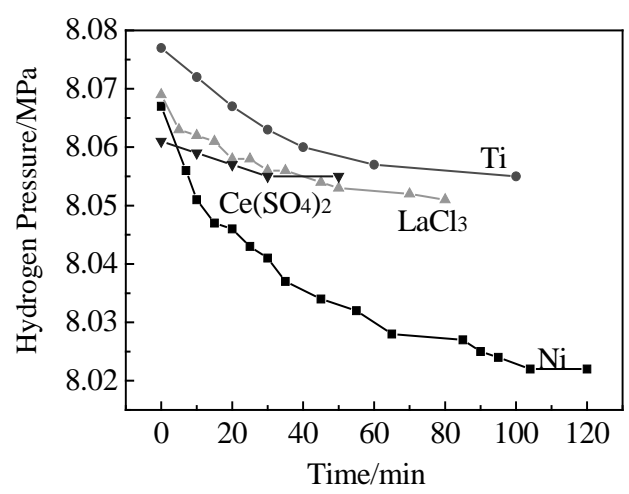

Fig.3 The rehydrogenation of $\mathrm{LiAlH}_{4}$ doped with $1 \mathrm{~mol} \% \mathrm{Ni}$, Ti, $\mathrm{Ce}\left(\mathrm{SO}_{4}\right)_{2}$ and $\mathrm{LaCl}_{3}$

Table 2 The rehydrogenation amount of $\mathrm{LiAlH}_{4}$ and $\mathrm{LiAlH}_{4}$ doped with $1 \mathrm{~mol} \% \mathrm{Ni}, \mathrm{Ti}, \mathrm{Fe}, \mathrm{Ce}\left(\mathrm{SO}_{4}\right)_{2}$ and $\mathrm{LaCl}_{3}(\omega / \%)$

\begin{tabular}{cccc}
\hline Dopants & $\begin{array}{c}\text { Hydrogen } \\
\text { adsorption } \\
\text { amount }\end{array}$ & Dopants & $\begin{array}{c}\text { Hydrogen } \\
\text { adsorption } \\
\text { amount }\end{array}$ \\
\hline $\begin{array}{c}1 \mathrm{~mol} \% \\
\mathrm{Ce}\left(\mathrm{SO}_{4}\right)_{2}\end{array}$ & 0.14 & $1 \mathrm{~mol} \% \mathrm{Ti}$ & 0.22 \\
$1 \mathrm{~mol} \% \mathrm{LaCl}_{3}$ & 0.47 & $1 \mathrm{~mol} \% \mathrm{Ni}$ & 0.97 \\
\hline
\end{tabular}

\section{Conclusion}

1) Doping induces a marked decrease in the rate of hydrogen release. Particularly, doping with Fe presents the lowest dehydrogenation rate in the first and second steps.

2) Doping obviously decreases the initial temperature of hydrogen release except for doping with $\mathrm{LaCl}_{3}$. However, at the same time, the amountof hydrogen $\mathrm{r}$ elease also decreases. Doping with $\mathrm{Fe}$ induces the lowest temperature and amount of hydrogen release. Doping with Ni decreases the dehydrogenation temperature by $27{ }^{\circ} \mathrm{C}$ while the amount of hydrogen release has only a slight decrease.

3) Among the samples of $\mathrm{LiAlH}_{4}$ doped with $1 \mathrm{~mol} \% \mathrm{Ni}, 1$ mol\% Ti, $1 \mathrm{~mol} \% \mathrm{Ce}\left(\mathrm{SO}_{4}\right)_{2}$ and $1 \mathrm{~mol} \% \mathrm{LaCl}_{3}, \mathrm{LiAlH}_{4}$ doped with $1 \mathrm{~mol} \% \mathrm{Ni}$ presents the largest hydrogen absorption amount with about $0.97 \mathrm{wt} \%$. at $180{ }^{\circ} \mathrm{C}$ under about $8 \mathrm{MPa}$.

\section{References}

1 Elena David. J Mater Process Tech[J], 2005, (162 163): 169

2 Andreasena A, Veggea T, Pedersena A S. J Solid State Chem[J], 2005, 178: 3664

3 Bogdanović B, Schwickardi M. J Alloys Compd[J], 1997, (253 254): 1

4 Easton D S, Schneibel J H, Speakman S A. J Alloys Compd[J], 2005, 398: 245

5 Jun Chen, Nobuhiro Kuriyama, Qiang Xu et al. J Phys Chem [J], 
2001, B105: 11214

6 Mirna Resan, Michael Hampton D, Janice Lomness K. Int J Hydrogen Energ[J], 2005, 30: 1413

7 Blanchard D, Brinks H W, Hauback B C et al. Mater Sci Eng[J],
2004, B 108: 54

8 Balema V P, Wiench J W, Dennis K W et al. J Alloys Compd $[\mathrm{J}]$, 2001, 329: 108

\title{
不同催化剂对氢化铝锂 $\left(\mathrm{LiAlH}_{4}\right)$ 可逆性能的影响
}

\author{
郑雪萍 ${ }^{1}$, 李 平 $^{2}$, 曲选辉 ${ }^{2}$ \\ (1. 长安大学, 陕西 西安 710061) \\ (2. 北京科技大学, 北京 100083)
}

\begin{abstract}
摘 要: 通过 PCT(Pressure-Content-Temperature)设备研究了不同催化剂 $\mathrm{Ti} 、 \mathrm{Ni} F \mathrm{Fe} 、 \mathrm{Ce}\left(\mathrm{SO}_{4}\right)_{2}$ 和 $\mathrm{LaCl}_{3}$ 对 $\mathrm{LiAlH}_{4}$ 可逆储氢性能的影响。 结果表明掺杂明显降低了试样的放氢速率, 此外除了 $\mathrm{LaCl}_{3}$, 其他的掺杂还降低了试样的放氢温度, 试样的放氢量也明显地下降了。掺杂 $1 \mathrm{~mol} \% \mathrm{Ni}, 1 \mathrm{~mol} \% \mathrm{Ti}, 1 \mathrm{~mol} \% \mathrm{Ce}\left(\mathrm{SO}_{4}\right)_{2}$ 和 $1 \mathrm{~mol} \% \mathrm{LaCl}_{3}$ 的 $\mathrm{LiAlH}_{4}$ 可逆吸氢的研究发现, 在 $180{ }^{\circ} \mathrm{C}$ 和 $8 \mathrm{MPa}$ 氢压的条件下, 掺杂 $1 \mathrm{~mol} \%$ $\mathrm{Ni}$ 的试样表现出了最好的吸氢性能, 其吸氢量达到了 $0.97 \%$ (质量分数)。
\end{abstract}

关键词：催化剂；可逆储氢；放氢; $\mathrm{LiAlH}_{4}$

作者简介: 郑雪萍, 女, 1975 年生, 博士, 长安大学, 陕西 西安 710061, 电话: 029-82337340, E-mail: zxp2004b@yahoo.com.cn 